\section{DRINK ABUSE}

Alcoholism

By Neil Kessel and Henry Walton. Pp. 174. (London: Macgibbon and $\mathrm{Kee}, 1966)$.$30 s . net.$

Alcorol is a "good familiar creature if it be well us'd"; the consequences of ill using it are described in this book by Prof. Kessel and Dr. Walton.

The book begins with chapters defining alcoholism, and describing the nature and effects of alcohol. A section on different patterns of drinking in relation to the social milieu is followed by one discussing the personality of alcoholics and another on the possible causes of alcoholism. The clinical features of the disease and its effects on the patient's family are covered in three chapters, and the book ends with discussions on treatment and its results and on the public health aspects of alcoholism.

The book is intended for the "general reader", but one hopes that many doctors will include themselves under that heading. Kessel and Walton present evidence of the inability of many doctors to appreciate that this condition requires more knowledge and understanding than is implied by a simple injunction to "pull yourself together and cut down your drinking".

The book certainly succeeds in describing the present state of knowledge about alcoholism and does not gloss over our profound ignorance about many aspects of it. The short chapter on the results of treatment, for example, points out the almost complete lack of properly collected data on the effects of treatment. Wisely, the authors are in no way dogmatic about any of the methods of treatment now in use.

On two aspects one must be cautious in interpreting the clinical evidence put forward. In relation to the personalities of alcoholics and to the stages of becoming an alcoholic, Kessel and Walton perhaps lean a little too heavily on their wide knowledge of alcoholic patients. No evidence is presented about the distribution of certain personality traits among the non-alcoholic population and the value of the discussion about these traits in alcoholies is therefore dubious. Similarly, while most alcoholics probably go through the stages of drinking described here, there is no evidence on the proportion of "social drinkers" who may reach many of these stages and safely remain there or even reverse their course.

This is an interesting, well written book on an important medico-social problem. Potential buyers of this hardbacked edition should note that it was first published in 1965 by Penguin Books at $4 s$.

S. L. Morrison

\section{FUNGI AND INCOMPATIBILITY IN FUNGI}

\section{Fungi}

An Introduction. By Lilian E. Hawker. (Hutchinson University Library.) Pp. 216. (London: Hutchinson and Co. (Publishers), 1966.) 13s. 6d.

\section{Incompatibility in Fungi}

Edited by Karl Esser and John R. Rapor. (A Symposium held at the 10th International Congress of Botany, Edinburgh, August 1964.) Pp. viii + 124. (Berlin and New York: Springer-Verlag, 1965.) 24 D.M.

Professor Hawker has set out "to provide a concise account of the fungi, for university students reading botany or microbiology for a first degree", and hopes "that it will be of use to both junior and advanced students". Have these aims been achieved ? The book is certainly concise and is written with a succinct economical style. In order to keep within the requirements of the series it has been necessary to limit the number of illustrations and references. The restricted bibliography is regrettable because although a number of recent developments have been touched on, the student whose appetite has been whetted will often be unable to track down the source of information. All the figures have been specially prepared by the author, mostly re-drawn from other publications, and are grouped together to form whole-page illustrations. This gives a pleasing impression of uniformity. There are no photographs.

The most serious criticism is that in attempting to encompass almost all the major groups of fungi, insufficient space has been available to treat some topics adequately. It may be questioned, for example, whether even an advanced student needs to know much about, say, the Lagenidiales, the Trichomycetes, the Coronophorales, Coryneliales, Myriangiales or Microthyriales. A number of other topics receive too scanty attention, such as the hormone control of sexual reproduction in Achlya, the mechanism of basidiospore discharge (surely few mycolo. gists now think that surface tension provides the necessary force), genetics of fungi (there is no mention of parasexual recombination or of multiple allele heterothallism) and hyphal analysis in the Polyporaceae. The mechanisms of peridiole projection in Cyathus striatus and Sphaerobolus are not fully explained. Virus transmission by zoospores of Olpidium is not mentioned, nor the breakdown of resistance to Synchytrium endobioticum in some potato varieties.

Another criticism is that phylogenetic speculation reccives undue emphasis. Since the evidence for many of supposed relationships is so slight, it might have been better to omit this altogether to make space for established fact.

The merits of the book are that it is authoritative, compact, concise and cheap, but most undergraduates, and certainly the advanced students, will need to do a good deal of reading elsewhere to provide themselves with sufficient factual information.

Incompatibility in Fungi is a written record of the papers and discussion during a symposium on this topic at the Edinburgh Botanical Congress in 1964. Since it is not proposed to publish in full the proceedings of this congress it is particularly valuable to have a published account of this stimulating session conceived by Professor Raper. Following a brief introduction by him there is a paper by Esser on heterogenic incompatibility in Podospora anserina, which Mather (in the final paper) regards as a mechanism restricting outbreeding, an isolating mechanism, a step on the road to speciation. A paper by Ahmad on incompatibility in yeasts draws special attention to the mutation of mating-type alleles. Bistis attempts to analyse the function of the mating-type locus in filamentous Ascomycetes. The meat of the book is devoted to the problems associated with tetrapolar Basidiomycetes with contributions by Day on genetics of tetrapolar incompatibility, Ellingboe on somatic recombination in Schizophyllum (giving details of a novel mechanism called "specific factor transfer") and Prud'homme on somatic recombination in Coprinus. Snider gives a detailed account of methodology for studying nuclear migration and discusses possible mechanisms. Perhaps the most stimulating papers are those by Dick on "Physiological Aspects of Tetrapolar Incompatibility" (which attempts to analyse by immunological methods biochemical differences between incompatible strains) and Parag on "Genetic Investigation into the Mode of Action of Genes Controlling Self-incompatibility and Heterothallism in Basidiomycetes". Without disrespect, Parag's paper can be understood far better in print than it could when originally delivered. It examines two alternative hypotheses to explain the mode of action of incompatibility factorsthe complementation hypothesis and the oppositional inhibition hypothesis - and proposes a series of genetical experimonts which should discriminate between them.

The book ends with two more general papers, one by Burnett on "The Natural History of Recombination Systems" and one by Mather on "The Genetical Interest 